\title{
Greener Is Better: First Approach for the Use of Natural Deep Eutectic Solvents (NADES) to Extract Antioxidants from the Medicinal Halophyte Polygonum maritimum L.
}

\author{
Iva Rukavina ${ }^{1}$, Maria João Rodrigues ${ }^{1}$, Catarina G. Pereira ${ }^{1}\left(\mathbb{D}\right.$, Inês Mansinhos ${ }^{2}{ }^{\mathbb{D}}$, Anabela Romano ${ }^{2} \mathbb{D}$, \\ Sylwester Ślusarczyk $\left.{ }^{3}{ }^{(}\right)$, Adam Matkowski ${ }^{3}(-)$ and Luísa Custódio ${ }^{1, *}(\mathbb{C}$ \\ 1 Centro de Ciências do Mar (CCMAR), Campus de Gambelas, Universidade do Algarve, Ed. \\ 7, 8005-139 Faro, Portugal; Iva.Rukavina@imbrsea.eu (I.R.); mjrodrigues@ualg.pt (M.J.R.); \\ cagpereira@ualg.pt (C.G.P.) \\ 2 Campus de Gambelas, MED-Mediterranean Institute for Agriculture, Environment and Development, \\ Faculdade de Ciências e Tecnologia, Universidade do Algarve, Ed. 8, 8005-139 Faro, Portugal; \\ ifmansinhos@ualg.pt (I.M.); aromano@ualg.pt (A.R.) \\ 3 Department of Pharmaceutical Biology and Biotechnology, Botanical Garden of Medicinal Plants, Wroclaw \\ Medical University, 50-556 Wroclaw, Poland; sylwester.slusarczyk@umed.wroc.pl (S.Ś.); \\ pharmaceutical.biology@wp.eu (A.M.) \\ check for \\ * Correspondence: lcustodio@ualg.pt
} updates

Citation: Rukavina, I.; Rodrigues, M.J.; Pereira, C.G.; Mansinhos, I.; Romano, A.; Ślusarczyk, S.; Matkowski, A.; Custódio, L. Greener Is Better: First Approach for the Use of Natural Deep Eutectic Solvents (NADES) to Extract Antioxidants from the Medicinal Halophyte Polygonum maritimum L. Molecules 2021, 26, 6136. https://doi.org/ $10.3390 /$ molecules 26206136

Academic Editors: Soran

Maria Loredana and

Lucian Copolovici

Received: 24 August 2021

Accepted: 7 October 2021

Published: 11 October 2021

Publisher's Note: MDPI stays neutral with regard to jurisdictional claims in published maps and institutional affiliations.

Copyright: (c) 2021 by the authors. Licensee MDPI, Basel, Switzerland. This article is an open access article distributed under the terms and conditions of the Creative Commons Attribution (CC BY) license (https:// creativecommons.org/licenses/by/ $4.0 /)$.

\begin{abstract}
In this study, natural deep eutectic solvents (NADES) formed by choline chloride (ChCl), sucrose, fructose, glucose, and xylose, were used to extract antioxidants from the halophyte Polygonum maritimum L. (sea knotgrass) and compared with conventional solvents (ethanol and acetone). NADES and conventional extracts were made by an ultrasound-assisted procedure and evaluated for in vitro antioxidant properties by the radical scavenging activity (RSA) on the 2,2-diphenyl-1-picrylhydrazyl (DPPH) radical, oxygen radical absorbance capacity (ORAC), and copper chelating activity (CCA). Samples were profiled by liquid chromatography (LC)-electrospray ionization (ESI)-QTOF-MS analysis. ChCl:fructose was more efficient in the DPPH assay, than the acetone extract. $\mathrm{ChCl}$ :sucrose and $\mathrm{ChCl}$ :fructose extracts had the highest ORAC when compared with the acetone extract. NADES extracts had higher CCA, than the acetone extract. The phenolic composition of the NADES extracts was less complex than the conventional extracts, but the proportions of major antioxidants, such as flavonols and flavan-3-ols, were similar in all the solvents. Myricitrin was the major flavonoid in all of the samples, while gallic acid was the main phenolic acid in the conventional extracts and present in a greater amount in $\mathrm{ChCl}$ :fructose. Results suggest that NADES containing $\mathrm{ChCl}$ and sucrose/fructose can replace conventional solvents, especially acetone, in the extraction of antioxidants from sea knotgrass.
\end{abstract}

Keywords: NADES; green chemistry; antioxidant extraction; halophytes

\section{Introduction}

Organic solvents such as methanol, ethanol, and acetone are commonly used in the conventional extraction of natural compounds, due to their high extraction and separation capacities [1]. However, their use has several disadvantages, including high solvent consumption, long extraction times, and low reuse potential, leading to a consequently higher price of the extraction process [2]. Moreover, these organic solvents have a negative impact on the environment, due to their toxicity, volatility, solubility, and flammability [3]. Green chemistry had tackled the pollution problem with the identification of environmentally friendly solvents and/or separation processes and has the legislative support of the EU environmental policy $[4,5]$. One of the possible suggested green solvents are, for example, ionic liquids (ILs), which are liquid salts at room temperature made of different cations (e.g., alkyl-imidazolium, pyridinium, ammonium, phosphonium) and inorganic anions (e.g., 
acetate, trifluoroacetate, trifluoromethyl sulfate) [6]. When compared with conventional solvents, ILs have a higher solubility, tuneability, and stability, a lower melting point and vapor pressure, and no volatility and flammability. Nevertheless, ILs still exhibit low biodegradability, high costs, and some constituents are toxic [4,7,8]. Deep eutectic solvents (DES) are novel liquid salts. In addition, their principle is that a hydrogen bond acceptor (HBA), generally quaternary ammonium salts such as choline chloride $(\mathrm{ChCl})$, combined with different hydrogen bond donors (HBD), including amines, alcohols, carboxylic acids, sugars, and vitamins, in a specific molar ratio, result in a mixture with a relative melting point lower than their individual components [7,9]. ILs and DES have similar physicochemical properties, but DES are easier and more affordable to synthesize and store [8]. Moreover, DES can be tailored to produce combinations with suitable physicochemical features that allow for the extraction of a specific group of bioactive molecules, for a particular purpose [10].

A few molecules, including sugars and choline, are present in high amounts in microbes, mammals, and plants cells and show the same properties as DES. In other words, they change their state from solid to liquid when mixed in a proper ratio [11,12]. The hypothesis is that the mixture of the primary metabolites forms an alternative media to water and lipids in the living organisms, which enables the synthesis of poorly water-soluble or insoluble molecules (e.g., rutin, cellulose, and lignin), and biochemical reactions in harsh environmental conditions such as drought, cold, and salt stress [10]. This concept led to the discovery of natural deep eutectic solvents (NADES), a new generation of DES, consisting of a mixture of primary metabolites such as sugars, organic acid, amino acids, and chlorine derivates [3]. NADES have several advantages over conventional extraction and ILs, including lower cost, biodegradability, and reduced toxicity $[3,4,7,8]$. NADES have been applied for the extraction of several bioactive natural products from marine and terrestrial sources, with high potential future use in commercial purposes, including hydrophilic and lipophilic compounds from Fucus vesiculosus [13], phlorotannins from brown algae [14], anthocyanins from blueberry peels [15] and gray berry [16], anthocyanins and phenolics from grape (Vitis vinifera) [7,9,17], flavonoids from Japanese pagoda tree (Sophora japonica), onion (Allium cepa), broccoli (Brassica oleracea var. italica), cranberry (Vaccinium sp.), plum (Prunus sp.), rosemary (Salvia rosmarinus), and pepper (Piper nigrum) [18-20], phenolic acids from Lonicerae japonicae [1], polyphenols from dittany (Origanum dictamnus), marjoram (Origanum majorana), mint (Mentha spicata), sage (Salvia officinalis), and fennel (Foeniculum vulgare) [21], phenylethanes and phenylpropanoids from Rhodiola rosea L [22], and steroidal saponins from Dioscoreae nipponicae rhizome [23].

Polygonum maritimum L. (sea knotgrass) is a Mediterranean-Atlantic halophyte species that occurs in Mediterranean and Black Sea coasts and reaches its northern limits in the Channel Islands, England, and Belgium. Ethanol and acetone extracts from sea knotgrass display multiple biological properties, including in vitro anti-diabetic, anti-inflammatory, anti-aging, anti-bacterial, and anti-fungal [24-28]. The phytochemical analysis of the extracts made from leaves and roots allowed the identification of several bioactive compounds belonging to different classes, such as tannins, saponins, flavonoids, terpenoids, cardiac glycosides, fatty acids, phenols, alcohols, and phytosterols $[25,26]$. Therefore, sea knotgrass has a promising medical, cosmetic, and nutritional application, and can be cultivated in saline conditions while maintaining its biochemical properties [29]. In this work, we evaluated the efficiency of NADES as a possible green replacement for conventional solvents in the extraction of antioxidant compounds from sea knotgrass, in the context of the sustainable exploitation of this species as a source of bioactive products to be applied in the food industry, as antioxidant food additives.

\section{Results and Discussion}

\subsection{Preparation and Optimization of NADES}

In this work, four NADES were prepared containing choline chloride $(\mathrm{ChCl})$ as a hydrogen bond acceptor (HBA) and glucose (Gluc), fructose (Fruc), xylose (Xyl), and su- 
crose (Suc) as hydrogen bond donors (HBD) (Table 1). These NADES fit into the green chemistry concept and the green extraction approach for the design of products to be profitable, while safe for human health and the environment $[1,4,30,31]$. Choline is inexpensive, non-toxic, biodegradable, and commonly used as a vitamin for animal feed [1,32]. In addition, it is provided by several foods, including eggs and dried soybeans [33], and is an essential element for several cellular processes, including the synthesis of the neurotransmitter acetylcholine and cell membranes phospholipids [34,35]. $\mathrm{ChCl}$ is synthesized from a trimethylamine, ethylene oxide, and hydrochloric acid $(\mathrm{HCl})$ in a reaction that has the E (environmental) Factor close to zero [36]. The E factor is used to assess the environmental impact of industrial production by calculating the kilograms of waste generated for each kilogram of the produced product [37]. The HBDs used in this study were the naturally occurring sugars Gluc, Fru, and Suc, which are used as sources of energy for living organisms, in food or sweeteners, with low toxicity concerns [38,39]. Xylose or wood sugar naturally occurs in hardwoods and agricultural residues [40] and builds cell walls of the cereal grains [30]. Xylose is poorly metabolized by monogastric animals including humans [30]. The low or nil toxicity of $\mathrm{ChCl}$ based NADES with Gluc, Fru, Suc, and Xyl was previously confirmed on fish (CCO) and human (MCF-7, HeLa, L929) cell lines, by inhibition of bacterial growth (Escherichia coli, Staphylococcus aureus, Salmonella enteritidis, and Listeria moncytogenes) and by phytotoxicity assays on the germination and early growth of wheat (Triticum aestivum) [3,18,41,42].

Table 1. List of natural deep eutectic solvents (NADES) prepared in this work and the corresponding molar ratio of hydrogen bond acceptor (HBA) and hydrogen bond donor (HBD), water content, as well as stability, time, and temperature of the synthesis.

\begin{tabular}{ccccc}
\hline HBA:HBD & Molar Ratio & Water Content & Stability & $\begin{array}{c}\text { Time/Temperature } \\
\text { of Synthesis }\end{array}$ \\
\hline ChCl:Fru & $1: 2$ & $30 \%$ & Stable & $15 \mathrm{~min} / 50{ }^{\circ} \mathrm{C}$ \\
\hline ChCl:Gluc & $1: 2$ & $30 \%$ & Unstable & $60 \mathrm{~min} / 55^{\circ} \mathrm{C}$ \\
\hline ChCl:Xyl & $1: 2$ & $30 \%$ & Unstable & $55 \mathrm{~min} / 55^{\circ} \mathrm{C}$ \\
\hline ChCl:Suc & $1: 2$ & $40 \%$ & Stable & $50 \mathrm{~min} / 55^{\circ} \mathrm{C}$ \\
\hline
\end{tabular}

HBA: Hydrogen bond acceptor; HBD: Hydrogen bond donor; Ch: Choline; Ch: Chloride; Suc: Sucrose; Fru: Fructose; Gluc: Glucose. * NADES were considered stable if no significant crystallization was observed after 7 days of storage in the dark at room temperature.

The ultrasound-assisted NADES synthesis method used in this work was more efficient in terms of time and energy saving, when compared to previously published results for the commonly used heating method of synthesis. The ultrasound-assisted synthesis took $15-60 \mathrm{~min}$ at the temperature of 50 or $55^{\circ} \mathrm{C}$ (Table 1$)$, while in the literature the heating method of synthesis for the same HBA:HBD mixture, although in some cases with different molar ratios, lasted from $1-6 \mathrm{~h}$ at $80^{\circ} \mathrm{C}[1,41]$.

When mixing the NADES components, a clear, transparent, and homogeneous liquid was formed. However, a crystalline precipitate was occasionally observed. Therefore, NADES were considered stable if no significant crystallization became visible after 7 days of storage, in the dark, at room temperature (approx. $20^{\circ} \mathrm{C}$ ). The combinations $\mathrm{ChCl}$ :Glu and $\mathrm{ChCl}: \mathrm{Xyl}$ exhibited crystallization after 2 to 3 days, and therefore, were not selected for further analysis. Dai et al. [43] studied different ratios of NADES components in terms of stability and reported that $\mathrm{ChCl}$ :Gluc, at a molar ratio of 1:2, also precipitate within 7 days. The same authors observed that $\mathrm{ChCl}: \mathrm{Xyl}$ at different molar ratios from those used in this work (2:1 and 3:1) were stable. At certain molar ratios, the hydroxyl or carboxyl groups from $\mathrm{HBA}$, in this case $\mathrm{ChCl}$, cannot combine with hydroxyl groups from $\mathrm{HBD}$, Gluc, and $\mathrm{Xyl}$, due to the unequal number of hydrogen bond donor and acceptor groups, resulting in the formation of a solid precipitate $[43,44]$. 


\subsection{In Vitro Antioxidant and Metal Chelating Properties}

It is essential to evaluate the antioxidant activity of the plant extracts with more than one assay, due to their high mixtures' complexity. In this work, the antioxidant activity was evaluated using three different in vitro chemical assays. The radical scavenging activity (RSA) towards the 2,2-diphenyl-1-picrylhydrazyl (DPPH) radical estimates the capacity of the tested sample to scavenge free radicals [45]. In addition, it is a standard, simple, fast, and widely used method for measuring the in vitro antioxidant activity of natural extracts [46]. In this work, the highest RSA towards the DPPH radical was obtained for the ethanol extract (half maximal effective concentration $-\mathrm{EC}_{50}$ value $=0.421 \mathrm{mg} / \mathrm{mL}$ ), followed by ChCl:Fru $\left(\mathrm{EC}_{50}=0.773 \mathrm{mg} / \mathrm{mL}\right)$, acetone $\left(\mathrm{EC}_{50}=1.725 \mathrm{mg} / \mathrm{mL}\right)$, and ChCl:Suc $\left(\mathrm{EC}_{50}=3.373 \mathrm{mg} / \mathrm{mL}\right)$ (Figure 1). When evaluating the DPPH RSA of acetone extracts from sea knotgrass cultivated in a greenhouse under different salinity irrigation conditions, Rodrigues et al. [29] found $\mathrm{EC}_{50}$ values in the range of $138-679 \mu \mathrm{g} / \mathrm{mL}$, depending on the salinity and harvest, which are lower than the values observed in this work.

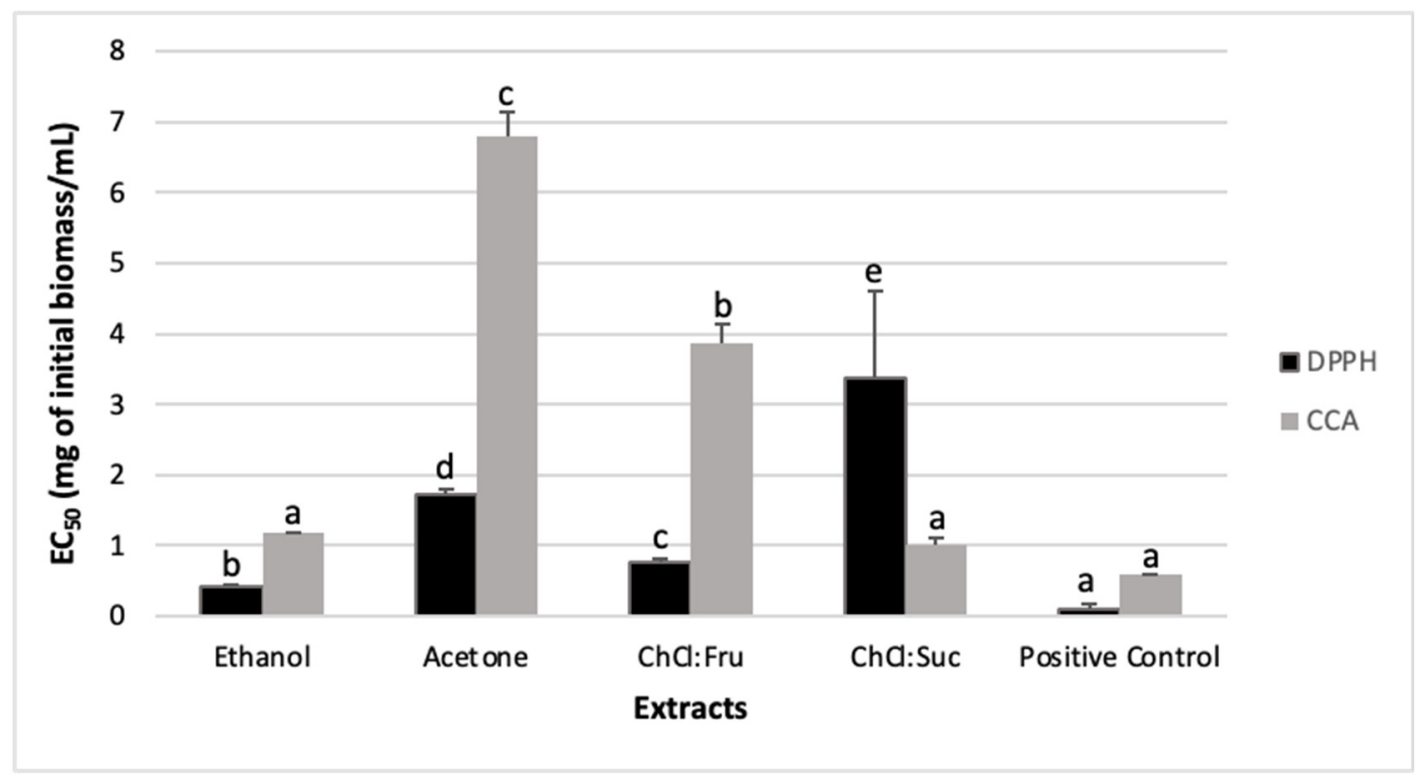

Figure 1. Radical scavenging activity (RSA) on 2,2-diphenyl-1-picrylhydrazyl (DPPH) and copper chelating activity (CCA), expressed as $\mathrm{EC}_{50}$ values (mg of initial biomass per $\mathrm{mL}$ ) of the extracts from Polygonum maritimum L. (sea knotgrass). Results are presented as mean values \pm standard error (SE) of at least six replicates $(n=6)$. Columns with different letters are significantly different at $p<0.05$ (Duncan's new multiple range test). Positive control for DPPH: BHT (butylated hydroxytoluene); positive control for CCA: EDTA (ethylenediaminetetraacetic acid).

The oxygen radical absorbance capacity (ORAC) assay measures the capacity of the tested sample to inhibit the oxidation of the peroxyl-radical [47]. It is considered as a biologically relevant method, since peroxyl radicals naturally occur in the living organisms, which are implicated in the propagation step of lipid peroxidation that is linked to the pathogenesis of several diseases, including atherosclerosis and asthma $[41,48,49]$. In the ORAC assay, the ethanol extract (328 $\mathrm{mg}$ trolox equivalentes (TE)/g) was the more efficient extract, followed by ChCl:Suc (153.51 mg TE/g), ChCl:Fru (148.12 mg TE/g), and acetone (49.34 mg TE/g) (Figure 2).

Methods targeting the chelating properties towards redox metals evaluate the capacity of the samples to form stable chelates with metal ions and complement the radical based methods, since excess free metals contribute to formation of the free radicals, and therefore, for the occurrence of oxidative stress [50]. Moreover, the accumulation of redox metals in the organism, such as copper, is implicated in the etiopathogenesis of several human diseases, such as Wilson's syndrome, Alzheimer's and Parkinson's diseases, and in several cancer types [51]. The extracts with the higher capacity to chelate copper were $\mathrm{ChCl}$ :Suc $\left(\mathrm{EC}_{50}=1.008 \mathrm{mg} / \mathrm{mL}\right)$ and ethanol extracts $\left(\mathrm{EC}_{50}=1.169 \mathrm{mg} / \mathrm{mL}\right)$, followed by ChCl:Fru 
$\left(\mathrm{EC}_{50}=3.868 \mathrm{mg} / \mathrm{mL}\right)$ and acetone extracts $\left(\mathrm{EC}_{50}=6.783 \mathrm{mg} / \mathrm{mL}\right)($ Figure 1$)$. The copper chelating activity (CCA) of the $\mathrm{ChCl}$ :Suc and ethanol extracts were significantly equivalent to the used positive control (ethylenediaminetetraacetic acid (EDTA), $\mathrm{EC}_{50}=0.579 \mathrm{mg} / \mathrm{mL}$ ) (Figure 1).

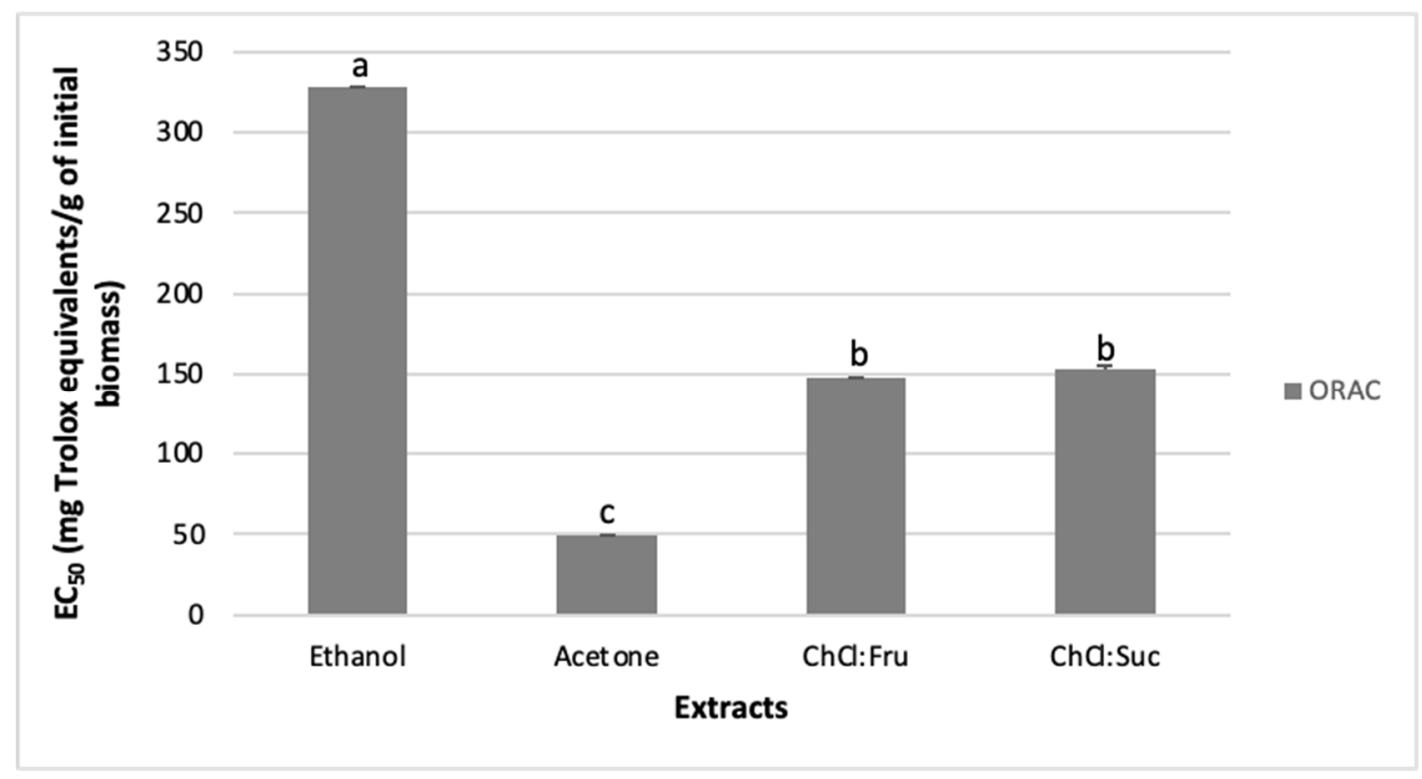

Figure 2. Oxygen radical absorbance capacity (ORAC) values (expressed as mg of Trolox equivalent (TE) per g of initial biomass) of tested extracts. Results are presented as mean values \pm standard error (SE) of at least six replicates $(\mathrm{n}=6)$. Columns with different letters are significantly different at $p<0.05$ (Duncan's new multiple range test).

When comparing the antioxidant activity of NADES and conventional extracts, it was observed that the ethanol extracts exhibited higher antioxidant properties, except in the CCA, where its activity was comparable to $\mathrm{ChCl:Suc} \mathrm{(Figure} \mathrm{2).} \mathrm{The} \mathrm{mixture} \mathrm{ChCl:Fru}$ always exhibited stronger antioxidant properties than the acetone extract (Figure 2). These results suggest that NADES, specifically $\mathrm{ChCl}$ :Suc and $\mathrm{ChCl}$ :Fru mixtures, could replace acetone and ethanol in the extraction of antioxidant compounds from sea knotgrass. These results follow other reports where the antioxidant activity of NADES extracts was generally higher or similar than those of extracts using conventional solvents, such as ethanol and methanol [21,41,45,52,53]. For example, Pal and Jadeja [52] observed that NADES extracts from onion peel made with $\mathrm{ChCl}$ and Suc, urea, and sorbitol had significantly (2-5 times) higher capacity to reduce iron than the aqueous methanol extract. In the same study, the DPPH RSA of ChCl:sorbitol was similar to the methanol extract [52]. In another study, the ORAC values for grape skin extracts made with $\mathrm{ChCl}$ and different sugars, including Gluc, Fru, and Xyl, were higher than those obtained with aqueous methanol extracts [41]. The DPPH RSA properties of Curcuma longa NADES extracts were higher than those obtained with the methanol extract, but lower when compared with the ethanol one [44]. These results were related to different extraction yields and different extracted chemical components $[41,44]$. All in all, the extraction efficiency of target functional molecules and the antioxidant activity suggest NADES as a sustainable alternative for the use of conventional solvents in the extraction of bioactive components from different plant species $[21,41,44,52,53]$.

\subsection{Phytochemical Characterization of Extracts}

Altogether, 51 peaks were detected, of which 43 were annotated (Table 2, Figure 3). Most of the peaks belonged to phenolic compounds representing flavonols, flavan-3-ols, and phenol carboxylic acids. The peaks corresponding to sucrose and fructose are likely to be artifacts. As expected, the NADES extracts were highly loaded with these sugars and the solid phase extraction (SPE) procedure may not be able to completely remove 
all of them. Moreover, this is the most likely reason for the apparently lower absolute amounts of the major flavonols in the analytical samples. The crude extracts had to be washed off the syrupy solvents and evaporated to dryness. Therefore, the final amounts eluted from the high-performance liquid chromatography (HPLC) column were reduced. However, the relative proportions between the individual flavonols and flavan-3-ols were largely retained (Figure 1). The general composition of the polyphenols regardless of the extraction solvent was similar to our previous studies [27-29] except for polygonophenone, the unique compound isolated by Kazantzoglou et al. [54], detected only in the earlier studies by Rodrigues et al. [27,28], and not detected in this study. This may be explained by the different plant biomass used and suggest the influence of environmental factors, rather than the genetic determination of this compound production in sea knotgrass. Conversely, myricitrin remained the main flavonoid compound in all our studies focusing on sea knotgrass $[27,28]$. The main quantitative difference between the NADES and conventional extracts was in the content of gallic acid, which was a major compound in the ethanol and acetone extracts, but only a minor, unquantifiable peak in NADES (Figure 1 and Table 2). Gallic acid (3,4,5-trihydroxylbenzoic acid) is common in different plant species, such as leafy vegetables and fruits. Gallic acid and its glucosides derivatives exhibit relevant biological properties, including antioxidant [55], which may have accounted, at least in part, to the highest antioxidant activity of the ethanol extract, in the DPPH and ORAC assays. The multivariate analysis [both principal component analysis (PCA) and partial least squares discriminant analysis (PLS-DA)] of the extract's composition shows clearly that NADES and ethanol and acetone extracts form two well-separated clusters (Figure 4). The variable importance in projection (VIP) analysis (Figure 4) indicated peaks that most contributed to the LC-MS profile differences between the extracts. Quercetin xyloside (peak 36) and gallic acid (peak 6) were the important contributors in the acetone extract, whereas citric acid (4) differentiated both NADES extracts. However, the peaks from sucrose (peak 2) and fructose (peak 3) which are both components of NADES also remained as most significant, probably due to the incomplete removal of solvent residues during sample preparation. 


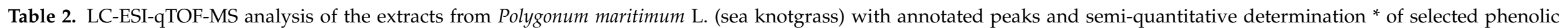
compounds. Identification was based on our previous reports on sea knotgrass [26-29].

\begin{tabular}{|c|c|c|c|c|c|c|c|c|c|c|c|}
\hline No. & Compounds & $t_{R}$ & UV & $m / z[\mathbf{M}-\mathbf{H}]^{-}$ & Formula & $\begin{array}{c}\text { MS }^{2} \\
\text { Main-Ion }\end{array}$ & $\begin{array}{c}\text { MS }^{2} \\
\text { Fragments }\end{array}$ & Ethanol & Acetone & ChCl:Sucrose & ChCl:Fructose \\
\hline 1 & 6-O-Galloyl-glucose & 0.9 & 272 & 331.0673 & $\mathrm{C}_{13} \mathrm{H}_{16} \mathrm{O}_{10}$ & 169.0110 & $271,211,151$ & 82.14 & 113.515 & & \\
\hline 2 & Sucrose & 1.0 & & $\begin{array}{c}341.1088,387.1149 \\
{[\mathrm{M}+\mathrm{FA}]}\end{array}$ & $\mathrm{C}_{12} \mathrm{H}_{22} \mathrm{O}_{11}$ & 179.0519 & 161 & & & & \\
\hline 3 & Fructose & 1.0 & & $\begin{array}{c}179.0545,225.0602 \\
{[\mathrm{M}+\mathrm{FA}]}\end{array}$ & $\mathrm{C}_{6} \mathrm{H}_{12} \mathrm{O}_{6}$ & 161.0421 & 149 & & & & \\
\hline 4 & Citric acid * & 1.2 & 209,272 & 191.0181 & $\mathrm{C}_{6} \mathrm{H}_{8} \mathrm{O}_{7}$ & 147.0322 & 127 & 0.58 & 0.12 & 1.107 & 0.95 \\
\hline 5 & Gallate 3-glucoside $\mathrm{e}^{\mathrm{E}}$ & 1.3 & 272 & 331.0667 & $\mathrm{C}_{13} \mathrm{H}_{16} \mathrm{O}_{10}$ & 169.0120 & $271,211,151,125$ & 0.05 & 0.965 & & \\
\hline 7 & $\begin{array}{l}\text { Acetyl-dihydroxyphenyl-D- } \\
\text { glucopyranoside }\end{array}$ & 1.5 & 275 & 329.0869 & $\mathrm{C}_{14} \mathrm{H}_{18} \mathrm{O}_{9}$ & 167.0328 & 152,283 & & 0.182 & 0.333 & \\
\hline 8 & Epigallocatechin ${ }^{\mathrm{E}}$ & 1.9 & 277 & 305.0661 & $\mathrm{C}_{15} \mathrm{H}_{14} \mathrm{O}_{7}$ & 167.0326 & $219,179,261,237$ & 2.30 & 5.919 & 0.365 & 0.84 \\
\hline 9 & Methylgallic acid-O-sulphate ${ }^{\mathrm{E}}$ & 2.5 & 257 & 262.9864 & $\mathrm{C}_{8} \mathrm{H}_{8} \mathrm{O}_{8} \mathrm{~S}$ & 183.0289 & & & & 3.17 & 2.16 \\
\hline 10 & Catechin $^{\mathrm{E}}$ & 4.4 & 275 & 289.0704 & $\mathrm{C}_{15} \mathrm{H}_{14} \mathrm{O}_{6}$ & 245.0798 & $203,221,151,137,125$ & 0.84 & 2.336 & 0.09 & \\
\hline 11 & D-threo-Hexitol ${ }^{\mathrm{E}}$ & 4.8 & 276 & 293.1232 & $\mathrm{C}_{12} \mathrm{H}_{22} \mathrm{O}_{8}$ & 131.0691 & & & 0.134 & & 0.25 \\
\hline 12 & Epicatechin ${ }^{\mathrm{E}}$ & 5.2 & 275 & 289.0706 & $\mathrm{C}_{15} \mathrm{H}_{14} \mathrm{O}_{6}$ & 245.0805 & $203,151,137,125$ & 0.91 & 0.840 & 0.593 & 0.66 \\
\hline 13 & Caffeic acid 3-sulfate ${ }^{E}$ & 5.6 & 306 & 258.9906 & $\mathrm{C}_{9} \mathrm{H}_{8} \mathrm{O}_{7} \mathrm{~S}$ & 179.0330 & 135 & 1.21 & 0.881 & 0.236 & 0.14 \\
\hline 14 & $p$-Coumaric acid-glucoside ${ }^{\mathrm{E}}$ & 5.8 & 279 & 325.0932 & $\mathrm{C}_{15} \mathrm{H}_{18} \mathrm{O}_{8}$ & 163.0376 & 119 & 1.18 & 1.001 & 0.570 & 1.19 \\
\hline 16 & Coumaroylquinic acid ${ }^{\mathrm{E}}$ & 7.6 & 275 & 337.0933 & $\mathrm{C}_{16} \mathrm{H}_{18} \mathrm{O}_{8}$ & 191.0540 & 173,163 & & 0.422 & & \\
\hline 17 & Coumaroylquinic acid $^{\mathrm{E}}$ & 7.8 & 275 & 337.0921 & $\mathrm{C}_{16} \mathrm{H}_{18} \mathrm{O}_{8}$ & 191.0542 & 173,163 & & 0.947 & 0.434 & 0.25 \\
\hline 18 & Epigallocatechin gallate ${ }^{\mathrm{E}}$ & 7.9 & 275 & 457.0776 & $\mathrm{C}_{22} \mathrm{H}_{18} \mathrm{O}_{11}$ & 169.0117 & 305,125 & 0.86 & 0.417 & 0.210 & 0.22 \\
\hline 19 & Gallocatechin gallate $\mathrm{E}^{\mathrm{E}}$ & 8.2 & 276 & 457.0779 & $\mathrm{C}_{22} \mathrm{H}_{18} \mathrm{O}_{11}$ & 169.0120 & 305,125 & 0.68 & 1.285 & 1.273 & 0.44 \\
\hline 20 & Ethylgallate sulfate ${ }^{\mathrm{E}}$ & 8.4 & 277 & 277.0010 & $\mathrm{C}_{9} \mathrm{H}_{10} \mathrm{O}_{8} \mathrm{~S}$ & 197.0436 & 182 & 0.31 & 0.430 & 0.620 & \\
\hline 21 & $\begin{array}{l}\text { Ent-Epicatechin-ent-epicatechin } \\
\text { 3-gallate }{ }^{\mathrm{E}}\end{array}$ & 8.5 & 274 & 729.1454 & $\mathrm{C}_{37} \mathrm{H}_{30} \mathrm{O}_{16}$ & 289.0708 & $269,125,407,169,433$ & & 0.428 & & \\
\hline 22 & Myricetin-galloylglucoside $\mathrm{F}^{\mathrm{F}}$ & 8.7 & 273 & 631.0944 & $\mathrm{C}_{28} \mathrm{H}_{24} \mathrm{O}_{17}$ & 479.0826 & 316,169 & 1.49 & 1.174 & 0.513 & 0.30 \\
\hline 23 & Dihydroferulic acid 4-O-glucuronide ${ }^{\mathrm{E}}$ & 8.9 & & 371.0977 & $\mathrm{C}_{16} \mathrm{H}_{20} \mathrm{O}_{10}$ & 249.0596 & 175,121 & & 0.180 & & 0.18 \\
\hline 24 & Ent-Epicatechin-ent-epicatechin ${ }^{\mathrm{E}}$ & 9.2 & & 577.1349 & $\mathrm{C}_{30} \mathrm{H}_{26} \mathrm{O}_{12}$ & 289.0690 & $407,125,161,245,381$ & 0.55 & 0.443 & 0.341 & 0.23 \\
\hline 25 & $\begin{array}{l}\text { Ent-Epicatechin-ent-epicatechin } \\
\text { 3-gallate }{ }^{\mathrm{E}}\end{array}$ & 9.3 & & 729.1457 & $\mathrm{C}_{37} \mathrm{H}_{30} \mathrm{O}_{16}$ & 289.0708 & $269,125,407,169,433$ & 2.00 & 2.684 & 0.983 & \\
\hline 26 & Myricetin $3^{\prime}$-glucoside ${ }^{F}$ & 9.5 & & 479.0833 & $\mathrm{C}_{21} \mathrm{H}_{20} \mathrm{O}_{13}$ & 316.0221 & & 1.43 & 0.675 & & 0.39 \\
\hline 27 & Quercetin 3-(2" -galloylglucoside $)^{\mathrm{F}}$ & 9.9 & & 615.0994 & $\mathrm{C}_{28} \mathrm{H}_{24} \mathrm{O}_{16}$ & 463.0878 & $300,313,271,241,169$ & 2.01 & 3.744 & 0.736 & 0.32 \\
\hline 28 & Nepetin $4^{\prime}$-glucoside ${ }^{\mathrm{F}}$ & 10.0 & & 477.1036 & $\mathrm{C}_{22} \mathrm{H}_{22} \mathrm{O}_{12}$ & 313.0553 & $433,169,163$ & 0.27 & 0.357 & & 0.16 \\
\hline
\end{tabular}


Table 2. Cont.

\begin{tabular}{|c|c|c|c|c|c|c|c|c|c|c|c|}
\hline No. & Compounds & $t_{R}$ & UV & $m / z[\mathbf{M}-\mathbf{H}]^{-}$ & Formula & $\begin{array}{c}\text { MS }^{2} \\
\text { Main-Ion }\end{array}$ & $\begin{array}{c}\text { MS }^{2} \\
\text { Fragments }\end{array}$ & Ethanol & Acetone & $\mathrm{ChCl}$ :Sucrose & ChCl:Fructose \\
\hline 29 & Gossypetin 8-O-glucoside ${ }^{\mathrm{F}}$ & 10.2 & & 479.0832 & $\mathrm{C}_{21} \mathrm{H}_{20} \mathrm{O}_{13}$ & 317.0290 & 169 & 2.38 & 5.326 & 0.807 & 0.32 \\
\hline 30 & Myricetin 3-O-rhamnoside ${ }^{F}$ & 10.4 & $218,263,351$ & 463.0889 & $\mathrm{C}_{21} \mathrm{H}_{20} \mathrm{O}_{12}$ & 316.0230 & 300 & 62.71 & 96.190 & 23.852 & 18.71 \\
\hline 31 & Epicatechin-3-gallate $^{\mathrm{E}}$ & 10.5 & 262,354 & 441.0844 & $\mathrm{C}_{22} \mathrm{H}_{18} \mathrm{O}_{10}$ & 169.0124 & $289,245,125$ & & & & \\
\hline 32 & Quercetin-3-O-galactoside & 10.6 & 262,355 & 463.0885 & $\mathrm{C}_{21} \mathrm{H}_{20} \mathrm{O}_{12}$ & 300.0276 & & 12.26 & 24.270 & 3.234 & 3.66 \\
\hline 33 & Quercetin-3-O-glucoside ${ }^{\mathrm{F}}$ & 10.8 & 265,352 & 463.0891 & $\mathrm{C}_{21} \mathrm{H}_{20} \mathrm{O}_{12}$ & 300.0275 & & 5.74 & 10.412 & 2.398 & 1.96 \\
\hline 34 & Catechin 3-O-rutinoside ${ }^{\mathrm{E}}$ & 11.1 & 278 & 597.1838 & $\mathrm{C}_{27} \mathrm{H}_{34} \mathrm{O}_{15}$ & 357.0983 & $387,417,315,459,239$ & & & 0.01 & 0.07 \\
\hline 35 & NI & 11.2 & & 449.2036 & $\mathrm{C}_{27} \mathrm{H}_{30} \mathrm{O}_{6}$ & 269.1387 & 209 & & & & 0.13 \\
\hline 37 & Rhamnetin 3-galactoside $\mathrm{F}^{\mathrm{F}}$ & 11.8 & 275,351 & 477.1042 & $\mathrm{C}_{22} \mathrm{H}_{22} \mathrm{O}_{12}$ & 315.0494 & 299,462 & 0.43 & 0.596 & 1.470 & \\
\hline 38 & Quercitrin $\mathrm{F}$ & 11.9 & 272,348 & 447.0937 & $\mathrm{C}_{21} \mathrm{H}_{20} \mathrm{O}_{11}$ & 300.0272 & 284,255 & 3.91 & 7.597 & 0.343 & 0.94 \\
\hline 39 & NI & 12.3 & & 415.1991 & & 161.0418 & 179 & 0.61 & 0.843 & 0.237 & 0.40 \\
\hline 40 & Myricetin ${ }^{F}$ & 12.5 & 276 & 317.0302 & $\mathrm{C}_{15} \mathrm{H}_{10} \mathrm{O}_{8}$ & 178.9978 & $151,137,287$ & 0.31 & 0.842 & 0.310 & 0.01 \\
\hline 41 & NI & 12.7 & & 583.1100 & & 300.0269 & 463 & & & & \\
\hline 42 & NI & 12.8 & & 471.0569 & $\mathrm{C}_{22} \mathrm{H}_{16} \mathrm{O}_{12}$ & 193.0127 & $301,319,178,257$ & 0.11 & & & \\
\hline 43 & Myricetin O-glucopyranoside $\mathrm{F}$ & 12.9 & 277 & 479.0827 & $\mathrm{C}_{21} \mathrm{H}_{20} \mathrm{O}_{13}$ & 317.0296 & & 0.13 & 0.290 & & \\
\hline 44 & Dihydroxyflavanone-sulfate ${ }^{\mathrm{F}}$ & 13.2 & & 367.0148 & $\mathrm{C}_{15} \mathrm{H}_{12} \mathrm{O}_{9} \mathrm{~S}$ & 287.0548 & 151,135 & 0.29 & 0.140 & & \\
\hline 47 & Trihydroxyflavanone-sulfate $\mathrm{F}^{\mathrm{F}}$ & 13.6 & & 383.0075 & $\mathrm{C}_{15} \mathrm{H}_{12} \mathrm{O}_{10} \mathrm{~S}$ & 303.0503 & 151 & 0.07 & 0.139 & & \\
\hline 48 & Quercetin $\mathrm{F}$ & 14.9 & 369 & 301.0347 & $\mathrm{C}_{15} \mathrm{H}_{10} \mathrm{O}_{7}$ & 151.0012 & $179,273,255,229$ & 0.19 & 0.281 & & \\
\hline 49 & Isorhamnetin ${ }^{\mathrm{F}}$ & 15.6 & & 315.0503 & $\mathrm{C}_{16} \mathrm{H}_{12} \mathrm{O}_{7}$ & 300.0272 & 271,255 & 0.09 & 0.328 & & \\
\hline 50 & Dihydroxy-8-oxooctadec-12-enoate & 17.1 & & 327.2176 & $\mathrm{C}_{18} \mathrm{H}_{32} \mathrm{O}_{5}$ & 211.1332 & $229,291,171$ & & & & \\
\hline 51 & Trihydroxy-9-octadecenoic acid & 18.1 & & 329.2329 & $\mathrm{C}_{18} \mathrm{H}_{34} \mathrm{O}_{5}$ & 211.1327 & $229,283,311,171$ & & & & \\
\hline
\end{tabular}

The content $\mathrm{mg} / \mathrm{g}$ extract and dry weight $(\mathrm{dw})$ are expressed as epicatechin $(\mathrm{E})$ and isoquercitrin $(\mathrm{F})$ equivalents, respectively; NI: Not identified. 


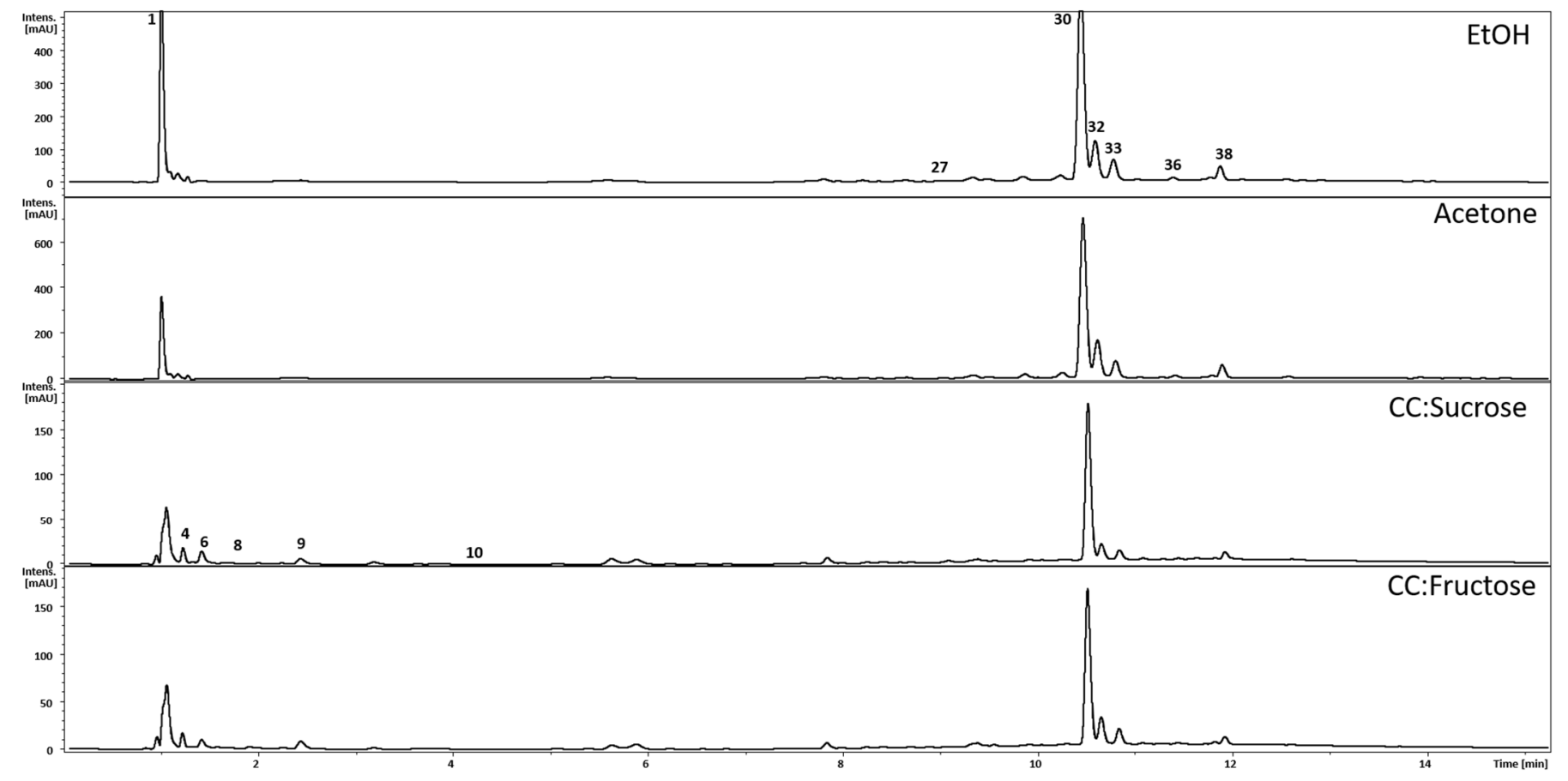

Figure 3. Examples of average HPLC chromatograms of Polygonum maritimum L. (sea knotgrass) extracts (UV $254 \mathrm{~nm}$ ). The major peaks are numbered according to Table 2 . The relative signal intensities shown on the $X$-axes are significantly stronger in both acetone and ethanol extracts than in NADES.

\section{Polygonum maritimum extrcts 0-(Sucrose, Fructose), 1-(EtOH, Acetone)}

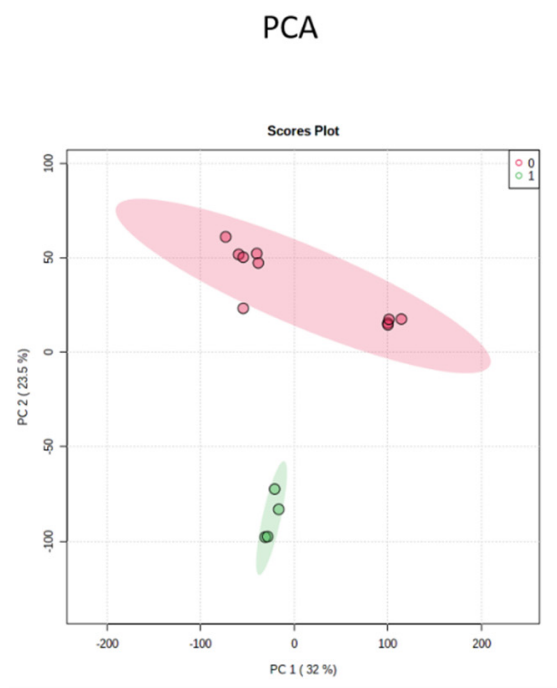

PLS-DA(Partial Least Squares Discriminant Analysis)

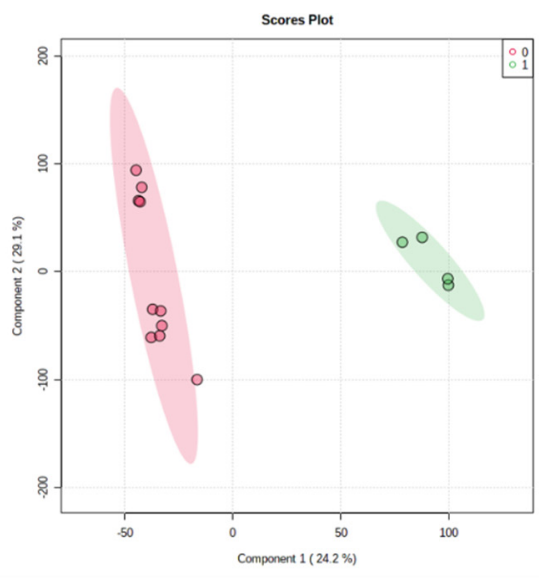

VIP-The most importance variable in projection

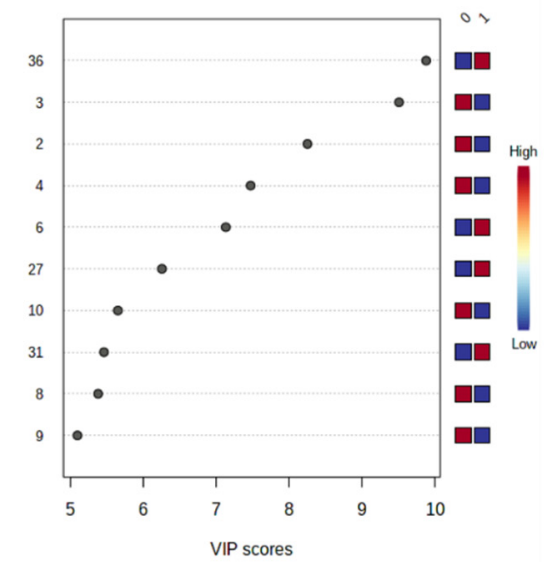

Figure 4. Multivariate analysis (principal component analysis (PCA) and partial least square discriminant analysis (PLS-DA) of phytochemical (LC-MS) data showing the clustering of samples depending on the solvents. NADES extracts are shown as red circles and ethanol and acetone as green circles. The variable importance in the projection (VIP) chart shows peaks (numbered as in Table 2) that most contribute to the differentiation between the extracts. 


\section{Materials and Methods}

\subsection{Chemicals}

Acetone and methanol were obtained from Valente and Ribeiro (Lisbon, Portugal). Ethanol (96\%) was purchased from "AGA-Álcool e Géneros Alimentares", S.A. (Lisbon, Portugal). Monobasic potassium phosphate was from Merck (Darmstadt, Germany), while dibasic potassium phosphate, iron (II) chloride $\left(\mathrm{FeCl}_{2}\right)$, ferrozine, ethylenediaminetetraacetic acid (EDTA), pyrocatechol violet (PV), copper sulfate $\left(\mathrm{CuSO}_{4}\right)$, sodium acetate, choline chloride, glucose, fructose, sucrose, and xylose were provided by VWR International (Leuven, Belgium). Panreack AppliChem ITW Reagents (Barcelona, Spain) supplied fluorescein and Acros Organics (Geel, Belgium) provided 2,2'-azobis (2-amidinopropane) dihydrochloride (AAPH) and Trolox. Sigma-Aldrich (Lisbon, Portugal) delivered DPPH and butylated hydroxytoluene (BHT).

\subsection{Plant Material}

The leaves and stems of sea knotgrass were harvested in the south of Portugal in Fuzeta island (N $\left.37^{\circ} 2^{\prime} 33.079^{\prime \prime}, \mathrm{W} 7^{\circ} 44^{\prime} 47.321^{\prime \prime}\right)$ in August of 2017 and identified by Luísa Custódio, according to the morphological characteristics. A voucher herbarium specimen was placed in the XtremeBio laboratory under the number XBH22.1. The plant material was freeze dried for 3 days, reduced to powder using a coffee mill, and stored at $-20{ }^{\circ} \mathrm{C}$ before analysis.

\subsection{Conventional Extraction}

Dried biomass was mixed with acetone and ethanol in the ratio of 1:40 (w/v) [26]. An ultrasound-assisted extraction was performed in an ultrasonic bath (USC-TH, VWR, Portugal), with a capacity of $5.4 \mathrm{~L}$, frequency of $45 \mathrm{kHz}$, a supply of $230 \mathrm{~V}$, and a tub heater of $400 \mathrm{~W}$, with temperature control made by a LED display.

The obtained extracts were filtered (Whatman No.4) and the solvent was completely removed in a rotary evaporator under reduced pressure and temperature (approximately $40^{\circ} \mathrm{C}$ ). The crude ethanol extract was dissolved in ethanol at the concentration of $1 \mathrm{mg} / \mathrm{mL}$, while the crude acetone extract was dissolved at the same concentration in methanol. The extracts were stored in the dark at $4{ }^{\circ} \mathrm{C}$, until analysis.

\subsection{Extraction Using NADES}

\subsubsection{Preparation of NADES}

NADES were prepared according to published protocols, with some modifications $[1,20,41]$. $\mathrm{ChCl}$ was used as an HBA and Gluc, Fruc, $\mathrm{Xyl}$, and Suc were selected as HBD. The components were previously dried in an incubator for $24 \mathrm{~h}$ at $60{ }^{\circ} \mathrm{C}$ [41]. $\mathrm{ChCl}$ was mixed with every HBD at the molar ratio of 1:2 [1]. The mixture was incubated in an ultrasonic bath, as described in Section 3.3, in closed glass flasks from 15 to $60 \mathrm{~min}$ at $50{ }^{\circ} \mathrm{C}$ for $\mathrm{ChCl}$ :Gluc, and $55^{\circ} \mathrm{C}$ for $\mathrm{ChCl}$ :Fruc, $\mathrm{Xyl}$, and Suc, until homogeneous and colorless liquids were formed [1,20]. Distilled water (30-40\%, w:w) was added to NADES [1,20,41], leading to less viscous solutions (Table 1). The obtained NADES were kept in the dark at room temperature [21].

\subsubsection{Extraction}

Dried biomass of sea knotgrass was mixed with NADES in the ratio of 1:40 $(w / v)$, and extraction was made in an ultrasonic bath (conditions described in Section 3.3) for $30 \mathrm{~min}$ at room temperature [26]. The extracts were then centrifuged (centrifuge Z 200 A, Hermle Labortechnik $\mathrm{GmbH}$, Germany) for $15 \mathrm{~min}$ at $5000 \mathrm{~g}$, and the supernatants were collected and used for further analysis. The extracts were kept in the dark at room temperature to avoid crystallization [41]. 


\subsection{Determination of In Vitro Antioxidant and Metal Chelating Properties}

In all the assays, if not mentioned differently, serial dilutions of the conventional extracts were used, ranging from 1 to $0.00195 \mathrm{mg} / \mathrm{mL}$ of the crude extract. For the NADES extracts, concentrations ranged from 25 to $0.0061 \mathrm{mg}$ initial biomass $/ \mathrm{mL}$ (which is, $\mathrm{mg}$ of dried plant biomass mixed with each $\mathrm{mL}$ of the solvent used in the extraction). Before the assays, the extracts made with NADES were warmed for $20 \mathrm{~min}$ at $60^{\circ} \mathrm{C}$, to reduce the viscosity. If the extract exhibited crystallization, it was incubated in the ultrasonic bath at $55^{\circ} \mathrm{C}$ and the frequency of $45 \mathrm{kHz}$ until the dissolution of the crystals. When the crystallization was not reverted, the extract was not used in the assays.

\subsubsection{Radical Scavenging Activity (RSA) towards DPPH}

The extracts were tested for RSA on the DPPH radical in 96-well microplates, according to the protocol described in Rodrigues et al. [56]. The extracts $(22 \mu \mathrm{L})$ were mixed with $200 \mu \mathrm{L}$ of DPPH $(120 \mu \mathrm{M}$ in ethanol) and incubated in the dark for $30 \mathrm{~min}$ at room temperature. Butylated hydroxytoluene (BHT) $(1-0.031 \mathrm{mg} / \mathrm{mL})$ and the solvent (ethanol, acetone or NADES) used for the extraction were used as positive and negative controls, respectively. The color control consisted of $22 \mu \mathrm{L}$ of the extracts mixed with $200 \mu \mathrm{L}$ of the solvent used for the extraction. The absorbance was measured at $492 \mathrm{~nm}$ using a microplate reader. RSA was expressed as the percentage of DPPH reduction, calculated in relation to the negative control, and as half maximal effective concentration ( $\mathrm{EC}_{50}$ values), when possible.

\subsubsection{ORAC Assay}

The ORAC assay was conducted in 96-well flat bottom black microplates, according to Gillespie et al. [57]. Conventional extracts were diluted at concentrations ranging from 0.05 to $0.00781 \mathrm{mg} / \mathrm{mL}$ with phosphate buffer $(75 \mathrm{mM}, \mathrm{pH} 7.0)$. NADES extracts were diluted at concentrations ranging from 0.05 to $0.0061 \mathrm{mg}$ initial biomass $/ \mathrm{mL}$, also with a buffer. Fluorescein $(150 \mu \mathrm{L}, 0.2 \mu \mathrm{M})$ was added to the well containing either $25 \mu \mathrm{L}$ of buffer for the blank control, $25 \mu \mathrm{L}$ of Trolox (positive control, 6.25, 12.5, 25, and $50 \mu \mathrm{M}$ ) or $25 \mu \mathrm{L}$ of the different concentrations. The reaction mixture was incubated for $10 \mathrm{~min}$ at $37^{\circ} \mathrm{C}$. Then, $25 \mu \mathrm{L}$ of AAPH $(150 \mathrm{mM})$ were added to the reaction mixture. The fluorescence kinetic read was run at $485 \mathrm{~nm}$ excitation and $530 \mathrm{~nm}$ emission for $90 \mathrm{~min}$ (interval time $5 \mathrm{~min}, 19$ cycles) at $37^{\circ} \mathrm{C}$ using a microplate reader (Infinite M200, Tecan Switzerland). The relative fluorescence of each well was calculated, and the fluorescence sample curves as well as the blank and Trolox standards curves were plotted. The ORAC activity of the samples was presented as the net area under the curve (Net AUC), which was calculated as the difference between the area under the sample curve and the area under the blank curve. Based on the Net AUC, the best concentration of $0.0625 \mathrm{mg} / \mathrm{mL}$ for both ethanol and acetone extracts was obtained (value closer to the middle value of the Trolox standards of AUC). For the NADES extracts, the best concentration was $0.0061 \mathrm{mg}$ initial biomass $/ \mathrm{mL}$. The ORAC values of the samples were finally expressed as $\mathrm{mg}$ Trolox equivalent (TE) per $\mathrm{g}$ of initial biomass using the quadratic regression equation with the known Trolox concentrations and Net AUC.

\subsubsection{CCA}

The extracts were tested for CCA in 96-well microplates according to Rodrigues et al. [56]. The samples $(30 \mu \mathrm{L})$ were mixed with $200 \mu \mathrm{L}$ of sodium acetate buffer $(50 \mathrm{mM}$, $\mathrm{pH}$ 6), $100 \mu \mathrm{L}$ of copper sulfate pentahydrate $\left(\mathrm{CuSO}_{4} \cdot 5 \mathrm{H}_{2} \mathrm{O}, 50 \mu \mathrm{g} / \mathrm{mL}\right.$, in distilled water), and $6 \mu \mathrm{L}$ of PV $(4 \mathrm{mM}$, in distilled water). EDTA $(1-0.03 \mathrm{mg} / \mathrm{mL})$ was used as a positive control, while the corresponding solvent (ethanol, acetone or NADES) was used as the negative control. The color control consisted of $30 \mu \mathrm{L}$ of the extracts mixed with $306 \mu \mathrm{L}$ of sodium acetate buffer. The absorbance was measured at $620 \mathrm{~nm}$ using a microplate reader (EZ Read 400, Biochrom United Kingdom). CCA was expressed as the percentage of PV elimination from the $\mathrm{Cu}$ complex by the sample in relation to the blank. 


\subsection{Chemical Characterization of the Extracts}

\subsubsection{Sample Preparation}

Each extract ( $8 \mathrm{mg}$ each) was dissolved in $2 \mathrm{~mL}$ of ultra-pure water, acidified with $0.2 \%(v / v)$ formic acid, and purified by SPE using the Oasis HLB 3 cc Vac Cartridge, 60 $\mathrm{mg}$ (Waters Corp., Milford, MA). The cartridges were washed with $2 \mathrm{~mL} 0.5 \%(v / v)$ aqueous methanol to remove carbohydrates, and then washed with $2 \mathrm{~mL} 80 \%(v / v)$ aqueous methanol to elute phenolics. The phenolic fraction was re-evaporated, weighed accurately, and re-dissolved in $2 \mathrm{~mL} 80 \%$ methanol (acidified with $0.2 \%$ formic acid) to get $3 \mathrm{mg} / \mathrm{mL}$ concentration. The sample was then centrifuged $(23,000 \times g, 5 \mathrm{~min})$ and filtered $(0.22 \mu \mathrm{m})$ before liquid chromatography (LC)-electrospray ionization (ESI)-QTOF-MS analyses, that were performed in triplicate for three independent samples (stored at $-20{ }^{\circ} \mathrm{C}$ before analysis for no longer than 3 days).

\subsubsection{LC-(ESI)-QTOF-MS Analysis}

LC-(ESI)-QTOF-MS estimation of the polyphenol composition of the extracts was carried out on a Thermo Dionex Ultimate 3000 RS (Thermo Fischer Scientific, Waltham, MA, USA) chromatographic system, coupled to a Bruker Compact (Bruker, Billerica, MA, USA) quadrupole time-of flight (QTOF) mass spectrometer, consisting of a binary pump system, sample manager, column manager, and PDA detector. Separations were performed on a Kinetex C18 column $(2.1 \times 100 \mathrm{~mm}, 2.6 \mu \mathrm{m}$, Phenomenex, Torrance, CA, USA), with mobile phase A consisting of $0.1 \%(v / v)$ formic acid in water and mobile phase B consisting of $0.1 \%(v / v)$ formic acid in acetonitrile. A linear gradient from 7 to $50 \%$ phase $\mathrm{B}$ in phase A over 20 min was used to separate phenolic compounds. The flow rate was $0.3 \mathrm{~mL} / \mathrm{min}$ and the column was held at $30^{\circ} \mathrm{C}$. Spectra were acquired in a negative ion mode over a mass range from m/z 100 to 1500 with $5 \mathrm{~Hz}$ frequency. Operating parameters of the ESI ion source were as follows: Capillary voltage $3 \mathrm{kV}$, dry gas flow $6 \mathrm{~L} / \mathrm{min}$, dry gas temperature $200{ }^{\circ} \mathrm{C}$, nebulizer pressure 0.7 bar, collision radio frequency $700.0 \mathrm{~V}$, transfer time $100.0 \mu \mathrm{s}$, and pre-pulse storage $7.0 \mu \mathrm{s}$. Ultrapure nitrogen was used as drying and nebulizer gas, and argon was used as collision gas. Collision energy was set automatically from 15 to $75 \mathrm{eV}$ depending on the m/z of the fragmented ion. Acquired data were calibrated internally with sodium formate and introduced to the ion source at the beginning of each separation via a $20 \mu \mathrm{L}$ loop. Processing of the spectra was performed with Bruker DataAnalysis.

\subsubsection{LC-MS Data Processing and Compounds Annotation}

After data acquisition, the raw UPLC-QTOF-MS spectra (negative mode) were preprocessed using the ProfileAnalysis software (version 2.1, Bruker Daltonik GmbH, Bremen, Germany) with the following settings: Advanced bucket generation with a retention time range of $0-20 \mathrm{~min}$, a mass range of $100-800 \mathrm{~m} / \mathrm{z}$, each bucket (spectral bins) was formed with $1 \mathrm{~min}$ and $1 \mathrm{~m} / \mathrm{z}$ delta, 0.2 kernelizing value, without normalization, background subtraction, and time alignment. LC-MS analyses were processed with the find molecular features (FMF) function to create compounds (molecular features) with S/N- 3 for peak detection.

The DataAnalysis 4.3 software (Bruker Daltonics $\mathrm{GmbH}$, Bremen, Germany) provides a ranking according to the best fit of measured and theoretical isotopic patterns, within a specific mass accuracy window. The quality of the isotopic fit was expressed by the mSigmavalue. The peaks were matched using the SmartFormula3D function and sent to the MetFrag in silico fragmentation website for computer-assisted identification of the mass spectra, using the Bruker-Sumner MetaboBase ${ }^{\circledR}$ Plant Library (Bruker Corporation, Billerica, MA, USA) [56]. In addition, other databases were used to manually search for the structural identity of the metabolites and these included: HMDB (http:/ / www.hmdb.ca/, accessed on 1 May 2021), Mass Bank of North America (MoNA) (https:/ / mona.fiehnlab.ucdavis.edu, accessed on 1 May 2021), BiGG (http:/ /bigg.ucsd.edu/, accessed on 1 May 2021), PubChem (http:/ / pubchem.ncbi.nlm.nih.gov/, accessed on 1 May 2021), MassBank database ( 
http: / / www.massbank.jp, accessed on 1 May 2021), KEGG (www.genome.jp, accessed on 1 May 2021), and the Metlin database (http:/ / metlin.scripps.edu, accessed on 1 May 2021).

The annotated compounds were estimated quantitatively using isoquercitrin (CAS 48235-9 quercetin 3-O-glucopyranoside, Merck, Darmstadt, Germany) as a reference standard for flavonols (compounds marked with superscript $F$ in Table 2) and (-)-epicatechin (CAS 490-46-0, Supelco, Bellefonte, PA, USA) was used for other phenolics (compounds marked with superscript E in Table 2). Stock solutions of (-)-epicatechin and isoquercitrin were prepared in methanol at concentrations of 3.2 and $4.5 \mathrm{mg} / \mathrm{mL}$, respectively and kept frozen until analysis. Calibration curves for these two compounds were constructed based on seven concentration points (from 800 to $3.9 \mu \mathrm{g} / \mathrm{mL}$ ).

\subsection{Data Presentation and Statistical Analysis}

For data analysis, the results of the conventional solvents' extracts were converted to $\mathrm{mg}$ of initial plant dry biomass per $\mathrm{mL}$ of used solvent, based on the extraction yield, to allow for the comparison with the NADES results. The $\mathrm{EC}_{50}$ values were calculated for the ethanol extracts at a starting concentration of $4.23 \mathrm{mg}$ of initial dry plant biomass $/ \mathrm{mL}$, for the acetone extract at $20 \mathrm{mg}$ of initial plant dry biomass $/ \mathrm{mL}$, and for the NADES extracts at $25 \mathrm{mg}$ of initial dry plant biomass $/ \mathrm{mL}$. $\mathrm{EC}_{50}$ values were calculated by sigmoidal fitting of the data using GraphPad Prism for Windows v.8.4.0 (GraphPad Software, La Jolla California). The area under the curve for the ORAC assay was calculated using the same software. Differences between means were analyzed by One-way ANOVA followed by Duncan's new multiple range test $(p<0.05)$, using IBM SPSS Statistics for Windows v.25.0 (Armonk, New York: IBM Corp).

The LC-MS data in the form of the generated bucket table consisting of Rt:m/z pairs and the respective compound intensity were exported and uploaded to the MetaboAnalyst 5.0 [58] freeware (https: / / www.metaboanalyst.ca/) to estimate the missing values and to filter and normalize data (normalization by median). No transformation was generalized and the data matrix were mean-centered and divided by the square root of the standard deviation of each variable (Pareto scaling). The PCA score plot was used to present a natural correlation between the observations. To identify compounds contributing to differences between chromatographic profiles of ethanol, acetone, and NADES, we used the PLS-DA model with variable importance in projection (VIP) values (VIP $\geq 1.0$ ) and $p(\operatorname{corr}) \geq 0.5$.

\section{Conclusions}

For NADES optimization, those consisting of $\mathrm{ChCl}$ with sucrose $(1: 2$ with $40 \%$ of water), and fructose (1:2, 30\% of water) exhibited the best stability. The extract made with $\mathrm{ChCl}$ and fructose always exhibited stronger antioxidant properties than the acetone extract. The ethanol extracts exhibited higher antioxidant properties, but their CCA was comparable to the NADES containing $\mathrm{ChCl}$ and sucrose. The phenolic profile was less complex in the NADES extracts with the absence of gallic acid glucoside, but other major antioxidants, such as catechins as well as myricetin and quercetin glycosides were present in comparable proportions in all the solvents. To the best of our knowledge, this is the first report on the use of NADES to extract antioxidant compounds from halophyte plants, and our results suggest that those combining $\mathrm{ChCl}$, sucrose, and fructose (molar ratio 1:2) could replace acetone and ethanol in the extraction of antioxidants from sea knotgrass.

Author Contributions: Conceptualization, I.R.; funding acquisition, A.R. and L.C.; investigation, I.R., M.J.R., C.G.P., I.M., S.Ś., and A.M.; methodology, L.C.; project administration, L.C.; supervision, L.C.; writing — original draft, I.R.; writing—review and editing, I.M., A.R., A.M., and L.C. All authors have read and agreed to the published version of the manuscript.

Funding: This research was funded by the Foundation for Science and Technology (FCT) and Portuguese National Budget through projects UIDB/04326/2020 and PTDC/BAA-AGR/1391/2020 (Greenvalue: Exploring salt tolerant plants as sources of innovative food additives). Moreover, 
funding was received from Fundo Azul, by the project XtremeAquaCrops (implementation and optimization of an integrated multi-trophic aquaculture (IMTA) system for marine fish and aquaponic extremophile medicinal halophytes production, FA_05_2017_028). Inês Mansinhos (grant SFRH/BD/145243/201 is funded by national funds through FCT. Luísa Custódio was supported by the FCT Scientific Employment Stimulus (CEECIND/00425/2017).

Institutional Review Board Statement: Not applicable.

Informed Consent Statement: Not applicable.

Data Availability Statement: The dataset is available upon request from the corresponding author.

Acknowledgments: The LC-MS analyses were performed in the core facility of the Faculty of Pharmacy, Wroclaw Medical University, Laboratory of Structural Analysis with the valuable technical assistance of Hanna Czapor-Irzabek.

Conflicts of Interest: The authors declare no conflict of interest.

Sample Availability: Samples of extracts are available from the authors.

\section{References}

1. Peng, X.; Duan, M.-H.; Yao, X.-H.; Zhang, Y.-H.; Zhao, C.-J.; Zu, Y.-G.; Fu, Y.-J. Green extraction of five target phenolic acids from Lonicerae japonicae Flos with deep eutectic solvent. Sep. Purif. Technol. 2016, 157, 249-257. [CrossRef]

2. Ignat, I.; Volf, I.; Popa, V.I. A critical review of methods for characterisation of polyphenolic compounds in fruits and vegetables. Food Chem. 2011, 126, 1821-1835. [CrossRef]

3. Paiva, A.; Craveiro, R.; Aroso, I.; Martins, M.; Reis, R.L.; Duarte, A.R.C. Natural deep eutectic solvents-solvents for the 21st century. ACS Sustain. Chem. Eng. 2014, 2, 1063-1071. [CrossRef]

4. Anastas, P.; Eghbali, N. Green chemistry: Principles and practice. Chem. Soc. Rev. 2010, 39, 301-312. [CrossRef]

5. Zoboli, R.; Paleari, S.; Speck, S.; Asquith, M. Towards a Green Economy in Europe. EU Environmental Policy Targets and Objectives 2010-2050; European Environment Agency: København, Denmark, 2013; Volume 8, pp. 1-48. [CrossRef]

6. Berthod, A.; Ruiz-Angel, M.-J.; Carda-Broch, S. Ionic liquids in separation techniques. J. Chromatogr. A 2008, 1184, 6-18. [CrossRef] [PubMed]

7. Bubalo, M.C.; Vidović, S.; Redovniković, I.R.; Jokić, S. Green solvents for green technologies. J. Chem. Technol. Biotechnol. 2015, 90, 1631-1639. [CrossRef]

8. Mbous, Y.P.; Hayyan, M.; Hayyan, A.; Wong, W.F.; Hashim, M.A.; Looi, C.Y. Applications of deep eutectic solvents in biotechnology and bioengineering-promises and challenges. Biotechnol. Adv. 2017, 35, 105-134. [CrossRef] [PubMed]

9. Bubalo, M.C.; Ćurko, N.; Tomašević, M.; Ganić, K.K.; Redovniković, I.R. Green extraction of grape skin phenolics by using deep eutectic solvents. Food Chem. 2016, 200, 159-166. [CrossRef]

10. Panić, M.; Gunjević, V.; Radošević, K.; Bubalo, M.C.; Ganić, K.; Redovniković, I. COSMOtherm as an effective tool for selection of deep eutectic solvents based ready-to-use extracts from graševina grape pomace. Molecules 2021, 26, 4722. [CrossRef] [PubMed]

11. Choi, Y.H.; van Spronsen, J.; Dai, Y.; Verberne, M.; Hollmann, F.; Arends, I.; Witkamp, G.-J.; Verpoorte, R. Are natural deep eutectic solvents the missing link in understanding cellular metabolism and physiology? Plant Physiol. 2011, 156, $1701-1705$. [CrossRef] [PubMed]

12. Wen, Q.; Chen, J.-X.; Tang, Y.-L.; Wang, J.; Yang, Z. Assessing the toxicity and biodegradability of deep eutectic solvents. Chemosphere 2015, 132, 63-69. [CrossRef] [PubMed]

13. Obluchinskaya, E.; Pozharitskaya, O.; Zakharova, L.; Daurtseva, A.; Flisyuk, E.; Shikov, A. Efficacy of natural deep eutectic solvents for extraction of hydrophilic and lipophilic compounds from Fucus vesiculosus. Molecules 2021, 26, 4198. [CrossRef] [PubMed]

14. Obluchinskaya, E.D.; Daurtseva, A.V.; Pozharitskaya, O.N.; Flisyuk, E.V.; Shikov, A.N. Natural deep eutectic solvents as alternatives for extracting phlorotannins from brown algae. Pharm. Chem. J. 2019, 53, 243-247. [CrossRef]

15. Grillo, G.; Gunjević, V.; Radošević, K.; Redovniković, I.; Cravotto, G. Deep eutectic solvents and nonconventional technologies for blueberry-peel extraction: Kinetics, anthocyanin stability, and antiproliferative activity. Antioxidants 2020, 9, 1069. [CrossRef] [PubMed]

16. Velásquez, P.; Bustos, D.; Montenegro, G.; Giordano, A. Ultrasound-assisted extraction of anthocyanins using natural deep eutectic solvents and their incorporation in edible films. Molecules 2021, 26, 984. [CrossRef] [PubMed]

17. Panić, M.; Stojković, M.R.; Kraljić, K.; Škevin, D.; Redovniković, I.R.; Srček, V.G.; Radošević, K. Ready-to-use green polyphenolic extracts from food by-products. Food Chem. 2019, 283, 628-636. [CrossRef]

18. Zhao, B.-Y.; Xu, P.; Yang, F.-X.; Wu, H.; Zong, M.-H.; Lou, W.-Y. Biocompatible deep eutectic solvents based on choline chloride: Characterization and application to the extraction of rutin from sophora japonica. ACS Sustain. Chem. Eng. 2015, 3, $2746-2755$. [CrossRef]

19. Nam, M.W.; Zhao, J.; Lee, M.S.; Jeong, J.H.; Lee, J. Enhanced extraction of bioactive natural products using tailor-made deep eutectic solvents: Application to flavonoid extraction from flos sophorae. Green Chem. 2015, 17, 1718-1727. [CrossRef] 
20. Bajkacz, S.; Adamek, J. Development of a method based on natural deep eutectic solvents for extraction of flavonoids from food samples. Food Anal. Methods 2018, 11, 1330-1344. [CrossRef]

21. Bakirtzi, C.; Triantafyllidou, K.; Makris, D.P. Novel lactic acid-based natural deep eutectic solvents: Efficiency in the ultrasoundassisted extraction of antioxidant polyphenols from common native Greek medicinal plants. J. Appl. Res. Med. Aromat. Plants 2016, 3, 120-127. [CrossRef]

22. Shikov, A.N.; Kosman, V.M.; Flissyuk, E.V.; Smekhova, I.E.; Elameen, A.; Pozharitskaya, O.N. Natural deep eutectic solvents for the extraction of phenyletanes and phenylpropanoids of rhodiola rosea L. Molecules 2020, 25, 1826. [CrossRef]

23. Yang, G.-Y.; Song, J.-N.; Chang, Y.-Q.; Wang, L.; Zheng, Y.-G.; Zhang, D.; Guo, L. Natural deep eutectic solvents for the extraction of bioactive steroidal saponins from dioscoreae nipponicae rhizoma. Molecules 2021, 26, 2079. [CrossRef]

24. EL Haci, I.A.; Bekkara, F.A.; Mazari, W.; Hassani, F.; Didi, M.A. Screening of biological activities of polygonum maritimum 1. from algerian coast. Asian Pac. J. Trop. Biomed. 2013, 3, 611-616. [CrossRef]

25. Edrah, S.; Kumar, S. Preliminary phytochemical and antibacterial studies of olea europaea and polygonum maritimum lib-yan plants. Int. J. Sci. Res. 2014, 3, 1677-1680.

26. Rodrigues, M.J.; Custódio, L.; Lopes, A.; Oliveira, M.; Neng, N.R.; Nogueira, J.M.F.; Martins, A.; Rauter, A.P.; Varela, J.; Barreira, L. Unlocking the in vitro anti-inflammatory and antidiabetic potential of polygonum maritimum. Pharm. Biol. 2017, 55, 1348-1357. [CrossRef] [PubMed]

27. Rodrigues, M.J.; Slusarczyk, S.; Pecio, Ł.; Matkowski, A.; Salmas, R.E.; Durdagi, S.; Pereira, C.G.; Varela, J.; Barreira, L.; Custódio, L. In vitro and in silico approaches to appraise polygonum maritimum L. as a source of innovative products with anti-ageing potential. Ind. Crop. Prod. 2018, 111, 391-399. [CrossRef]

28. Rodrigues, M.J.; Matkowski, A.; Ślusarczyk, S.; Magné, C.; Poleze, T.; Pereira, C.; Custódio, L. Sea knotgrass (Polygonum maritimum L.) as a potential source of innovative industrial products for skincare applications. Ind. Crop. Prod. 2019, 128, 391-398. [CrossRef]

29. Rodrigues, M.J.; Monteiro, I.; Placines, C.; Castañeda-Loaiza, V.; Ślusarczyk, S.; Matkowski, A.; Pereira, C.; Pousão-Ferreira, P.; Custódio, L. The irrigation salinity and harvesting affect the growth, chemical profile and biological activities of Polygonum maritimum L. Ind. Crop. Prod. 2019, 139, 111510. [CrossRef]

30. Huntley, N.F.; Patience, J.F. Xylose: Absorption, fermentation, and post-absorptive metabolism in the pig. J. Anim. Sci. Biotechnol. 2018, 9, 4. [CrossRef]

31. Chemat, F.; Vian, M.A.; Cravotto, G. Green extraction of natural products: Concept and principles. Int. J. Mol. Sci. 2012, 13, 8615-8627. [CrossRef]

32. Workel, H.A. Quality and nutritional aspects of choline chloride. Krmiva 2004, 47, 101-106.

33. Zeisel, S.H.; Mar, M.-H.; Howe, J.C.; Holden, J.M. Concentrations of choline-containing compounds and betaine in common foods. J. Nutr. 2003, 133, 1302-1307. [CrossRef]

34. Institute of Medicine (US) Standing Committee on the Scientific Evaluation of Dietary Reference Intakes and its Panel on Folate, Other B Vitamins, and Choline. Dietary Reference Intakes for Thiamin, Riboflavin, Niacin, Vitamin B6, Folate, Vitamin B12, Pantothenic Acid, Biotin, and Choline; National Academies Press (US): Washington, DC, USA, 1998.

35. Craig, S.A.S. Betaine in human nutrition. Am. J. Clin. Nutr. 2004, 80, 539-549. [CrossRef]

36. Abbott, A.P.; Harris, R.C.; Ryder, K.S.; D'Agostino, C.; Gladden, L.F.; Mantle, M.D. Glycerol eutectics as sustainable solvent systems. Green Chem. 2011, 13, 82-90. [CrossRef]

37. Sheldon, R.A. The E Factor: Fifteen years on. Green Chem. 2007, 9, 1273-1283. [CrossRef]

38. PubChem. D-glucose compound. Available online: https:// pubchem.ncbi.nlm.nih.gov/compound/GLUCOSE (accessed on 21 March 2020).

39. PubChem. Sucrose. Available online: https://pubchem.ncbi.nlm.nih.gov/compound/Sucrose (accessed on 21 March 2020).

40. Sigma Aldrich. Xylose. Available online: https://www.sigmaaldrich.com/catalog/product/sial/x1500?lang=pt\&region=PT (accessed on 21 March 2020).

41. Radošević, K.; Ćurko, N.; Srček, V.G.; Bubalo, M.C.; Tomašević, M.; Ganić, K.K.; Redovniković, I.R. Natural deep eutectic solvents as beneficial extractants for enhancement of plant extracts bioactivity. LWT 2016, 73, 45-51. [CrossRef]

42. Radošević, K.; Bubalo, M.C.; Srček, V.G.; Grgas, D.; Dragičević, T.L.; Redovniković, I.R. Evaluation of toxicity and biodegradability of choline chloride based deep eutectic solvents. Ecotoxicol. Environ. Saf. 2015, 112, 46-53. [CrossRef]

43. Dai, Y.; van Spronsen, J.; Witkamp, G.-J.; Verpoorte, R.; Choi, Y.H. Natural deep eutectic solvents as new potential media for green technology. Anal. Chim. Acta 2013, 766, 61-68. [CrossRef]

44. Liu, Y.; Li, J.; Fu, R.; Zhang, L.; Wang, D.; Wang, S. Enhanced extraction of natural pigments from Curcuma longa L. using natural deep eutectic solvents. Ind. Crop. Prod. 2019, 140, 111620. [CrossRef]

45. Sirivibulkovit, K.; Nouanthavong, S.; Sameenoi, Y. Paper-based DPPH Assay for Antioxidant Activity Analysis. Anal. Sci. 2018, 34, 795-800. [CrossRef]

46. Kedare, S.B.; Singh, R.P. Genesis and development of DPPH method of antioxidant assay. J. Food Sci. Technol. $2011,48,412-422$. [CrossRef]

47. Karadag, A.; Ozcelik, B.; Saner, S. Bioencapsulation of beta-carotene in three different methods. In Proceedings of the XVII International Conference on Bioencapsulation, Groningen, The Netherlands, 24-26 September 2009. [CrossRef] 
48. Maitra, I.; Marcocci, L.; Droy-Lefaix, M.T.; Packer, L. Peroxyl radical scavenging activity of Ginkgo biloba extract EGb 761. Biochem. Pharmacol. 1995, 49, 1649-1655. [CrossRef]

49. Mylonas, C.; Kouretas, D. Lipid peroxidation and tissue damage. Vivo 1999, 13, $295-309$.

50. Wong, F.-C.; Yong, A.-L.; Ting, E.P.-S.; Khoo, S.-C.; Ong, H.-C.; Chai, T.-T. Antioxidant, metal chelating, anti-glucosidase activities and phytochemical analyses of selected tropical medicinal plants. Iran. J. Pharm. Sci. 2014, 13, 1409-1415.

51. Baldari, S.; Di Rocco, G.; Toietta, G. Current biomedical use of copper chelation therapy. Int. J. Mol. Sci. 2020, 21, 1069. [CrossRef]

52. Pal, C.B.T.; Jadeja, G.C. Deep eutectic solvent-based extraction of polyphenolic antioxidants from onion (Allium cepa L.) peel. J. Sci. Food Agric. 2019, 99, 1969-1979. [CrossRef]

53. Shang, X.; Tan, J.-N.; Du, Y.; Liu, X.; Zhang, Z. Environmentally-friendly extraction of flavonoids from cyclocarya paliurus (Batal.) iljinskaja leaves with deep eutectic solvents and evaluation of their antioxidant activities. Molecules 2018, 23, 2110. [CrossRef] [PubMed]

54. Kazantzoglou, G.; Magiatis, P.; Kalpoutzakis, E.; Skaltsounis, A.-L. Polygonophenone, the first mem-substituted natural product, from polygonum maritimum. J. Nat. Prod. 2009, 72, 187-189. [CrossRef]

55. Nam, S.-H.; Park, J.; Jun, W.; Kim, D.; Ko, J.-A.; El-Aty, A.M.A.; Choi, J.Y.; Kim, D.-I.; Yang, K.-Y. Transglycosylation of gallic acid by using Leuconostoc glucansucrase and its characterization as a functional cosmetic agent. AMB Express 2017, 7, 1-10. [CrossRef]

56. Rodrigues, M.J.; Soszynski, A.A.; Martins, A.; Rauter, A.P.; Neng, N.R.; Nogueira, J.M.F.; Varela, J.; Barreira, L.; Custódio, L. Unravelling the antioxidant potential and the phenolic composition of different anatomical organs of the marine halophyte Limonium algarvense. Ind. Crop. Prod. 2015, 77, 315-322. [CrossRef]

57. Gillespie, K.M.; Chae, J.M.; A Ainsworth, E. Rapid measurement of total antioxidant capacity in plants. Nat. Protoc. 2007, 2, 867-870. [CrossRef]

58. Chong, J.; Wishart, D.S.; Xia, J. Using metaboanalyst 4.0 for comprehensive and integrative metabolomics data analysis. Curr. Protoc. Bioinform. 2019, 68, e86. [CrossRef] 